\title{
LOSSES ON SALES OR EXCHANGES BETWEEN MEMBERS OF THE SAME FAMILY: \\ THE IN-LAW PROBLEM
}

Although losses on sales or exchanges of property may generally be deducted in computing taxable income, ${ }^{1}$ certain losses were specifically made non-deductible under section 24 of the Internal Revenue Code of $1939^{2}$ and are likewise non-deductible under section 267 of the new I954 Code. ${ }^{3}$ These sections disallow as deductions, among other things, losses on sales or exchanges transacted between members of the same family. ${ }^{4}$ The intent of Congress in this respect is clarified by its definition of "family"s which does not include in-laws."

The recent case of Stern $v$. Commissioner ${ }^{7}$ raised the interesting problem of whether a sale to a son-in-law could, nevertheless, be regarded as a sale within the family for this purpose because of the peculiar form which the transaction took. At the son-in-law's suggestion, title to the petitioner's former residence had been taken by the sonin-law and his wife, petitioner's daughter, as tenants by the entirety. The purchase check had been drawn on their joint bank account, but all funds therein were attributable to the son-in-law, and the daughter had not participated in any of the negotiations other than to join as a co-signer of the purchase-money mortgage. ${ }^{8}$ The Commissioner argued,

${ }^{1}$ INT. REV. CODE $§ 165,68$ A STAT. 49 (1954).

252 STAT. 464 (1938), 26 U.S.C. \& 24 (1946).

3 68A STAT. 78 (1954).

"INT. REv. CODE $§ 267$ (b) (r), 68A STAT. 78 (1954): "No deduction shall be allowed . . . in respect of losses from sales or exchanges of property, directly or indirectly, between ... members of a family. . ." Substantially the same provisions appeared in the 1939 Code. 52 STAT. 464 (1938), 26 U.S.C. \& 24 (b) (I) (A) (1946).

${ }^{5}$ INT. REv. CODE $\& 267$ (c) (4), 68A STAT. 79 (1954): "The family of an individual shall include only his brothers and sisters, ... spouse, ancestors, and lineal descendants. . ." The same provision was embodied in the 1939 Code. 52 STAT. 465 ( 1938 ), 26 U.S.C. $\S 24(\mathrm{~b})(2)$ (D) (r 946$)$. These provisions had their genesis in the r934 Code, 48 STAT. 69r, as amended, 26 U.S.C. $\$ 24(\mathrm{~b})(2)$ (D) (1940), and were enacted to prevent the abuse of family relations for the establishment of artificial tax losses. See H.R. REP. No. 704, 73d Cong., 2d Sess. 23 (1 934); SEN. REP. No. 558, 73d Cong., 2d Sess. (1934).

${ }^{6}$ Topek v. Comm'r, 9 T.C. 763,766 (1947) (son-in-law).

215 F.2d 701 (3d Cir. 1954), reversing, 21 T.C. 155 (1953).

${ }^{8}$ It has been held that the fact alone that one party contributes all or the greater part of the consideration does not of itself eliminate the possibility of an estate by the entirety. See, e.g., Hargett v. Hargett, 156 Fla. 730, 24 So.2d 305 (1946); Sutorius v. Mayor, 350 Mo. 1235, 170 S.W.2d 387 (1943); cf. Hudson v. Wright, 204 
nevertheless, that the joinder of the two as tenants by the entirety transformed the transaction from a sale to the son-in-law into a sale to the daughter.

The 'Tax Court ${ }^{9}$ sustained the Commissioner's argument by holding non-deductible the entire loss sustained by the father in the transaction. ${ }^{10}$ The Third Circuit, however, reversed, holding that, although traditional realty law espoused the fiction that man and wife are a single person, the tax law should be governed by practical realities. The important point, therefore, was who, as a matter of fact, was the purchaser. ${ }^{11}$ And looking to the questions of who negotiated the sale and who paid for the property, the court, with no difficulty, concluded that the son-in-law was in fact the buyer. ${ }^{12}$

The problem presented by the Stern case-whether and to what extent losses sustained in sales or exchanges with in-laws are deductible for tax purposes-would seem to be susceptible of three possible solutions. The entire loss can be held non-deductible on the ground that the transaction is actually a sale, albeit indirectly, by the taxpayer to another member of his family. Or the loss can be disallowed as a deduction proportionately to the interest the relative takes in the property. Or lastly, the entire loss can be held deductible on the ground that the relative is, if anything, a donee if he neither takes a part in, nor contributes consideration to, the transaction.

Disallowance of the entire loss, the first solution, can rest on either or both of two bases. First, if the relative of the taxpayer has, in fact, negotiated the sale and furnished all of the consideration, then the transaction is actually a sale to that relative, and the court should treat it as such regardless of the form in which it is cast.

Another basis on which total disallowance can be posited is an outright acceptance of the real property fiction that tenants by the entirety

Mo. 412, 103 S.W. 8 (1907) (where price paid came out of wife's separate funds, husband's interest subject to a constructive trust in her favor).

${ }_{21}$ T.C. 155 (1953).

${ }^{10}$ The Tax Court disallowed the loss under $\$ 24(\mathrm{~b})$ of the 1939 Code, since a tenancy by the entirety confers on each grantee ownership of the whole property and not just a part. See also Simister v. Comm'r, 4 T.C. 470 (1944); note 15 and accompanying text infra.

${ }_{11}$ Such a realistic approach was adopted in Charles J. Stamler, P-H I 943 TC MEM. DEC. [43,362 (1943); Moore v. Comm'r, I7 T.C. 1030 (1951); W.A. Drake, Inc. v. Comm'r, 3 T.C. 33 (1944).

${ }^{13} 2$ I5 F.2d 701, 705 (3d Cir. 1954). Cf. Saul v. Comm'r, P-H I947 TC MEM. DEC. T47,178 (I947); Powell v. Comm'r, 94 F.2d 483 (Ist Cir. 1938); Skinner v. Comm'r, 47 B.T.A. 624 (1942), aff'd, 138 F.2d 418 (6th Cir. 1943); Shoenberg v. Comm'r, 77 F.2d 446 (8th Cir. 1935). But of. Comm'r v. Hale, 67 F.2d 56I (Ist Cir. 1933). See also Note, 55 HARv. L. REv. 872 (1942). 
hold the land as one person, and that, therefore, the entire property has been sold to the relative. ${ }^{13}$ This point of view, adopted by the Tax Court in the Stern case, ignores the realities of the transaction, however, and, as pointed out by the Court of Appeals, it is doubtful that the solution of modern tax problems will be greatly enhanced by the invocation of abstract concepts of medieval property law.14 In cases such as Stern, therefore, the choice would seem more properly to have lain between the other two alternative solutions, depending upon the circumstances involved.

Accordingly, if the daughter in the Stern case had furnished a part of the consideration or had been instrumental in the negotiations which eventuated in the sale, then the Third Circuit might have held that the property was sold to the daughter to the extent that she had contributed a quid pro quo, and, to that extent, the loss should have been denied as a deduction. If, for example, the value of the daughter's interest, as measured by the amount she had contributed to its purchase, amounted to two-thirds of the total value of the property, then two-thirds of the loss should have been disallowed. This approach is suggested in part by Simister $v$. Commissioner, ${ }^{15}$ where a father sold a farm at a loss to his daughter and son-in-law as tenants in common. The court there held that the prohibition against deducting a loss on a family sale applied only to the half of the property taken by the daughter, but not to that half passing to the son-in-law, and allowed one-half of the loss to be deducted..$^{16}$ It will be noted, however, that though apportionment was accepted in this case as a solution, the amount apportioned to each party for tax purposes was determined by the tenancy-in-common concept of an undivided one-half interest rather than by the amount-of-contribution test suggested above. It is submitted that the latter test is better grounded in consistency and good sense.

The last of the three possible solutions-allowance of the entire loss as a deduction-would seem to be appropriate only in cases where the relative has contributed nothing, directly or indirectly, to the trans-

\footnotetext{
${ }^{23}$ See note Io supra; Rudick, Federal Tax Problems Relating to Property Owned in Joint Tenancy and Tenancy by the Entirety, 4 TAX L. REv. 3 (1948).

${ }^{14}$ Judge Maris, speaking for the Court of Appeals (215 F.2d 701, 705), quoted with approval Judge Hill's dissenting opinion in the Tax Court: "[T]he majority relies upon legal fiction in the effort to establish that a sale between the petitioner and his daughter was accomplished as a matter of law. The fiction relied upon belongs to the law of real property. It had its roots in the common law and was born centuries before income taxation was a gleam in the fiscal eye of government. The fiction argues that husband and wife are one. In the enactment and administration of revenue laws, fact rather than fiction is made to prevail."

${ }_{15} 4$ T.C. 470 (1944). See note 10 supra.

${ }^{10}$ Cf. Morgan v. Finnegan, 182 F.2d 649 (8th Cir. 1950).
} 
action and so is actually a donee rather than a purchaser. Thus, if a son-in-law, as in the Stern case, has actually furnished the entire consideration for a purchase from his father-in-law and has simply taken title in his name and that of his wife, it cannot fairly be said that there has been a "sale" to the daughter. In substance, there has been an instantaneous gift to her of the interest she takes in the property. Such, in fact, appears to have been the situation in the Stern case, and, accordingly, the decision of the Third Circuit allowing deduction of the entire loss would seem to be sound.

Forrest E. CAMpbelL 